\title{
Lita Lundquist 2006. Tekstkompetence på fremmedsprog. Kø- benhavn: Forlaget Samfundslitteratur, 160 p. og en cd.
}

Lita Lundquist har gjort det igen: Hun har skrevet en fremragende lærebog til brug på universitetsniveau med inddragelse af den nyeste sprogvidenskabelige forskning og med udnyttelse af e-læringsprogrammer. Denne gang har hun, i naturlig forlængelse af sine tidligere arbejder med tekstlingvistik, kastet sig over læse-, skrive- og analysekompetence på fremmedsprog, kompetencer der er helt afgørende for kandidaternes senere virke som sprogmedarbejdere, men som der hidtil ikke har været tradition for at give systematisk undervisning i. På denne måde udfylder Tekstkompetence på fremmedsprog et hul i lærebogslitteraturen. Den muliggør en ny og savnet form for it-assisteret tværfaglig undervisning på sprogstudierne. Netop nu (foråret 2008) har vi således på Aarhus Universitet igangsat et seminar der bruger bogen som grundbog.

Bogen består af fem kapitler, en indledning og et efterord samt som virkelig nyskabning en cd med et tekstnavigeringsprogram. I første kapitel, Viden og fremmedsprog, behandles de tre typer af viden der ifølge forfatteren indgår i al tekstkompetence: viden om verden, viden om tekster og viden om sproget. De tre følgende kapitler behandler hver sin delkompetence, nemlig læsekompetence, analysekompetence og skrivekompetence. Endelig introducerer kapitel fem til brugen af de to it-programmer der refereres til gennem hele bogen.

Det er vigtigt at understrege at der er tale om et igangværende arbejde, og forfatteren opfordrer i introduktionen til "kollektiv indsats". På en lang række punkter bærer bogen da også præg af at være et foreløbigt resultat af et igangsat projekt med de fejl, mangler og unøjagtigheder der er naturlige for et sådant. For at tage et enkelt eksempel, så finder man intetsteds en definition af kohærensbegrebet der ellers spiller en central rolle bogen igennem. Denne form inspirerer imidlertid samtidig til deltagelse i den "kollektive indsats", og det er i dette lys de lejlighedsvis kritiske bemærkninger i det følgende skal ses.

Bogens overordnede koncept og struktur er glimrende. Selve begrebet tekstkompetence præciseres allerede på de første sider og bogens opbygning afspejler direkte de forskellige aspekter det indeholder. De praktiske kompetencer opdeles i delkompetencer der så indføres trinvist for til sidst at samles. For læsekompetencens vedkommende drejer det sig om emner som:

- $\quad$ Evnen til at kunne fastslå hvordan en tekst er placeret i sin kontekst.

- $\quad$ Evnen til at identificere hvilket vidensområde teksten handler om og anvende denne viden aktivt under læseprocessen.

- $\quad$ Evnen til at afgøre hvilken diskurs, genre og teksttype teksten tilhører. 


\section{4}

- $\quad$ Evnen til at forudsige hvilke karakteristiske træk man kan forvente at støde på senere i teksten.

- $\quad$ Evnen til at identificere sådanne træk i teksten og anvende dem som læsespor.

- $\quad$ Evnen til at anvende leksikalsk og syntaktisk viden til at identificere og 'navigere' langs sådanne læsespor for at skabe mening i teksten under læseprocessen.

For skrivning drejer det sig bl.a. om følgende delkompetencer:

- Evnen til at analysere situation og kommunikationens formål.

- Evnen til at afgøre hvilken genre og teksttype en given skriveopgave medfører.

- $\quad$ Evnen til at reproducere de karakteristiske stiltræk fra originaltekster fra samme genre og teksttype i skriveprocessen.

- $\quad$ Evnen til at anvende læsespor fra læseprocessen som skrivespor i skriveprocessen.

- $\quad$ Evnen til at anvende former der er typiske i fremmedsproget.

- $\quad$ Evnen til at undgå at reproducere træk der er typiske for dansk (modersmålet).

Et særlig fint træk ved bogen er de mange konkrete øvelser der giver en god mulighed for at forstå hvorledes den introducerede teori kan anvendes. Dette sammenholdt med den logiske trinopbygning gør bogen velegnet til direkte brug som lærebog i forbindelse med et kursus i tekstkompetence. Man kunne måske indvende at meget af det der forklares i kapitel 1 formodentlig tages for at være selvfølgeligheder af mange undervisere - men reflekterer man lidt over de erfaringer man har gjort sig i undervisningssituationer, opdager man nok at det er det så langt fra altid for ens studerende. En række punkter kan dog måske skabe forvirring. For eksempel brugen af vidensbegrebet. I en sammenhæng hvor det er tekstkompetence der er i fokus er der nok snarere tale om opfattelser eller synspunkter som de er til stede i kommunikationssammenhængen. I det hele taget kan det virke som om begrebet 'viden' spiller en lovlig central rolle, og det skal i hvert fald tolkes bredt hvis det - med meget god vilje - skal kunne anvendes som foreslået.

Et andet spørgsmål der presser sig på er: Hvad gør den studerende over for alle de mindre prototypiske tekster hun bliver udsat for i praksis? Vi er her ved et grundlæggende problem ved projektet. I (det vellykkede) forsøg på at pædagogisere kommer Lita Lundquist til at præsentere mange emner på en meget firkantet måde. Således lægger ikke mindst øvelserne op til at der er én ”rigtig 
løsning”. For mig at se løber man her en alvorlig risiko der består i at den studerende mister sansen for sprogets diversitet, hvilket kan virke kontraproduktivt mht. de kompetencer der skal opnås: Man tror på en endimensionel tolkning og på at der kun er én måde at kommunikere et budskab på. Denne fare burde der have været gjort meget klarere opmærksom på meget tidligere. Den omtales faktisk kun i 18 linjer på siderne 143-144. Bogen igennem forsøger forfatteren dog at råde bod på dette centrale problem ved at indføre læseren i alle de mange former for hensyn man må tage ved tekstlæsning og tekstproduktion - alle de forskellige parametre der også skal vægtes indbyrdes. Igen ser man dog intet eksempel på hvordan de kan komme i konflikt indbyrdes og hvordan man så må vægte ud fra diverse hensyn. Alle eksempler er valgt med pædagogisk omhu, så de ret klart illustrerer de pointer forfatteren gennemgår. Eksempelvalget er faktisk fremragende netop derfor; men det havde nok været en god idé at supplere med enkelte eksempler mod slut, hvor der opstod konflikt mellem de forskellige gennemgåede parametre. Hvis dette havde været vist ville ovennævnte fare formentlig være blevet imødegået i et vist omfang, men det ville naturligvis også have gjort indlæringen mere krævende for den studerende. Efter min opfattelse dog ikke mere krævende end den kan og bør være på universitetsniveau.

I et forsøg på at bidrage til den videre udvikling af projektet vil jeg nedenfor pege på nogle specifikke punkter jeg er faldet over og som nok bør tages op til overvejelse.

Et første alvorligt problem ligger i at den rosværdige pædagogiske stræben har den negative effekt at den får termer til at fremstå som uproblematiske. Disse er ikke indbyrdes veldefinerede. Jeg har ingen (umiddelbar) løsning på dette problem; men det bidrager til at det hele bliver meget firkantet og man risikerer at hæmme den dygtige sprogproducents fintfølende intuition ved at sætte for meget i kasser. Det er muligt man vinder mere end man taber; men er denne risiko indregnet i metoden? Burde man ikke minimalt diskutere hvad man kan gøre for at undgå faldgruber?

Generelt skal forfatteren roses for sit forsøg på at finde dækkende danske termer også på områder hvor der indtil nu kun har været få eller ingen behandlinger på dansk. Undertiden kan man dog blive lidt forvirret når disse termer præciseres som om de er alment gods. Således overrasker Lita Lundquists brug af udsigelsesmodaliteter (47f) mig. Hvorfra kommer den? Er der her ikke snarere tale om illokutionære modaliteter? Denne term ville også passe bedre ind i den anvendte terminologi, da begrebet udsigelse ellers ikke forekommer i bogen. I den sammenhæng er det endvidere heller ikke klart for mig hvad pragmatiske adverbier dækker. Man kan måske mere eller mindre gætte sig til det når man læser videre og ser anvendelsen af det, men det ville have været rart med et egentligt forsøg på definition. Det ville sikkert også være en god idé i en kommende udgave at udarbejde et stikordsregister, måske et glossar og et 


\section{6}

bedre krydsreferencesystem.

Det er oplagt at mange forskellige lingvistiske arbejder og teorier hver på sin måde har bidraget til vor forståelse af tekster og derfor med fordel kan inddrages i en lærebog om tekstkompetence. Bogen bærer da også præg af at forfatteren har forsøgt at samordne mange angrebsvinkler på de samme emneområder. Resultatet må i det store og hele karakteriseres som vellykket, ikke mindst takket være de mange udmærkede skemaer (undtagelsen er skemaet side 39). Disse har dog samtidig været medvirkende til en forenkling af problematikken som undertiden kan hæmme den kreative tænkning, fordi de ikke har taget højde for at der kan være konflikt mellem forskellige tilgange. Måske vil dette problem kunne løses (delvist) hvis man anvender en egentlig modulær metodologi. En sådan synes også at kunne gå fint i spænd med udviklingen af de medfølgende computerprogrammer som netop er bygget modulært op.

Trods den brede teoretiske orientering bærer den lingvistiske del af bogen dog præg af at være skrevet i det - meget vidende og kreative - lingvistiske miljø der findes på CBS (Handelshøjskolen i København). Det betyder at forskningsområder der står centralt her har fået høj prioritet, medens andre er gledet i baggrunden. I hvert fald på ét punkt har det haft en uheldig konsekvens. Således er det helt centrale fokaliseringsbegreb slet ikke omtalt på side 73 hvor begrebet informationsstruktur gennemgås, og det på trods af at der faktisk bruges et fokaliseringsbegreb i programmet TeXtRay (og det nævnes da også - men uden forklaring - på side 121 hvor TeXtRays opbygning omtales).

Det klassiske store problem inden for tekstlingvistik har været at få analyseniveauerne til at hænge sammen. Der har været foretaget adskillige forsøg på at skelne fx mellem makro- og mikrostrukturer; men den nærmere sammenhæng har næppe nogensinde været ordentlig afklaret. Det bliver den da heller ikke her; men Lita Lundquist har faktisk fået ganske godt fat i hvad hun kalder Global tekstsammenhæeng (94). Det er ellers et flygtigt fænomen der nemt slipper ud mellem fingrene, men som forfatteren fanger ganske godt i flugten takket være sit (lettere) metaforiske sprog, som i det hele taget giver en mere glidende læsning. Der er ingen tvivl om at billedsprog ofte har en fin pædagogisk virkning; men faren for at dette bliver på bekostning af præcision og klarhed lurer under overfladen, og således er jeg bange for at billedet med at "sætningen strømmer af sted” forvirrer mere end det klargør. Billeder skal være umiddelbart intuitivt forståelige. I øvrigt kræver netop dette afsnit om "Måder at ordne informationer på i engelsk og fransk - inden for sætningsgrænsen” efter min mening en grundig omarbejdning. Som det står nu er det alt for kortfattet og uden forsøg på forklaringer.

Bogen sluttes af med en introduktion til installering og anvendelse af de to it-programmer Navilire og TeXtRay som der gennem hele bogen refereres til. 
I det hele taget er det et stort plus ved bogen at disse programmer så at sige er integreret i den. Der er ingen tvivl om at øvelser ved hjælp af it-programmer kan være både spændende og lærerige. Jeg har dog her et hjertesuk. Der synes ikke at være blevet gjort noget ved det problem som har forfulgt disse pædagogiske programmer siden de første dukkede op for omkring 25 år siden: Programmerne lægger op til at der altid er én rigtig løsning; det er facitlistemodellen. Enhver der har arbejdet med sproglig analyse ved imidlertid at der altid vil være flere måder at analysere på. I firserne gav det anledning til en stor pædagogisk debat. Er den døet ud? Er vi ikke kommet videre?

I øvrigt må jeg erkende at jeg ikke har testet de to programmer grundigt nok til at udtale mig om deres gode og dårlige sider; men der er jo her i særlig grad tale om et arbejde i stadig udvikling og jeg kan kun anbefale læseren at gå i gang med programmerne og dermed være med til videreudviklingen af dem. Samtidig kan man ikke undgå at udbygge sin tekstkompetence på fremmedsprog.

Trods de forbehold jeg har fremført ovenfor er der tale om en glimrende og inspirerende bog, og de 'fejl' der er kan rettes, for det er jo et løbende projekt som forfatteren selv lægger op til at alle kan deltage i. Mine kritikpunkter skal ses i dette lys, og jeg kan kun opfordre læseren sig til at kaste sig ud i arbejdet med tekstkompetence på fremmedsprog.

Henning Nølke 
